\title{
Commentary
}

Open Access

\section{Applying lessons learnt from Ebola for effective COVID-19 response in Africa}

\author{
${ }^{*}$ Aiyenuro, A. E., ${ }^{2}$ Onyeani, C. O., and ${ }^{3}$ Uche, N. C. \\ ${ }^{1}$ Team Lead and Research Analyst, Research4Knowledge, Lagos, Nigeria \\ ${ }^{1}$ Network officer, Loving Gaze IO, SHOPS Plus Tuberculosis USAID Project \\ ${ }^{2}$ Department of Medical Laboratory Science, University of Nigeria, Nsukka \\ ${ }^{3}$ Quality Assurance Officer, Loving Gaze IO, SHOPS Plus Tuberculosis USAID Project \\ *Correspondence to: aiyenuroademola@gmail.com; +2348138642956
}

\begin{abstract}
:
The Ebola virus is transmitted to people from wild animals and spreads in the human population through human-to-human transmission via direct contact with blood, secretions, organs or other bodily fluids of infected people, and with surfaces and materials contaminated with these fluids. In December 2019, a novel coronavirus disease (COVID-19) caused by severe acute respiratory syndrome-coronavirus-2 (SARS-COV-2) emerged in Wuhan, China, attracting the notice of regional authorities and rapidly drawing global attention. In less than 4 months, COVID-19 spread through almost all countries and regions. The COVID-19 pandemic is wreaking havoc on the world economy, in addition to creating the current global public health crisis. According to the World Health Organization (WHO), 28,616 cases of Ebola were detected, and 11,310 people died during the outbreak in Guinea, Liberia and Sierra Leone. As of $17^{\text {th }}$ December 2020, COVID-19 has killed 1,658,062 people, and positive cases have topped 74 million globally. Africa has suffered several outbreaks of Ebola Virus Disease (EVD); learning from the past is a good way to prepare for the future. We hope to highlight some of the lessons learnt from Africa's response to previous epidemics that can help in the fight against the ravaging coronavirus pandemic.
\end{abstract}

Keywords: Ebola, COVID-19, WHO, transmission, global

Received Aug 5, 2020; Revised Jan 8, 2021; Accepted Jan 9, 2021

Copyright 2021 AJCEM Open Access. This article is licensed and distributed under the terms of the Creative Commons Attrition 4.0 International License <a rel="license" href="http://creativecommons.org/licenses/by/4.0/", which permits unrestricted use, distribution and reproduction in any medium, provided credit is given to the original author(s) and the source. Editor-in-Chief: Prof. S. S. Taiwo

\section{Appliquer les leçons tirées d'Ebola pour une réponse efficace au COVID-19 en Afrique}

\author{
${ }^{* 1}$ Aiyenuro, A. E., ${ }^{2}$ Onyeani, C. O., et ${ }^{3}$ Uche, N. C. \\ ${ }^{1}$ Chef d'équipe et analyste de recherche, Recherche4Connaissance, Lagos, Nigéria \\ ${ }^{1}$ Agent de réseau, Loving Gaze IO, Projet SHOPS Plus Tuberculosis USAID \\ ${ }^{2}$ Département des sciences de laboratoire médical, Université du Nigéria, Nsukka \\ ${ }^{3}$ Agent d'assurance qualité, Loving Gaze IO, Projet SHOPS Plus Tuberculosis USAID \\ *Correspondance à: aiyenuroademola@gmail.com; +2348138642956
}

\begin{abstract}
Abstrait:
Le virus Ebola est transmis aux humains par des animaux sauvages et se propage dans la population humaine par transmission interhumaine par contact direct avec du sang, des sécrétions, des organes ou d'autres fluides corporels de personnes infectées, et avec des surfaces et des matériaux contaminés par ces fluides. En décembre 2019, une nouvelle maladie à coronavirus (COVID-19) causée par le syndrome respiratoire aigu sévère-coronavirus-2 (SRAS-COV-2) est apparue à Wuhan, en Chine, attirant l'attention des autorités régionales et attirant rapidement l'attention mondiale. En moins de 4 mois, le COVID-19 s'est propagé dans presque tous les pays et régions. La pandémie de COVID-19 fait des ravages sur l'économie mondiale, en plus de créer la crise mondiale actuelle de santé publique. Selon l'Organisation mondiale de la santé (OMS), 28616 cas d'Ebola ont été détectés et 11310 personnes sont décédées au cours de l'épidémie en Guinée, au Libéria et en Sierra Leone. Au 17 décembre 2020, le COVID-19 avait tué 1658062 personnes et les cas positifs dépassaient 74 million dans le monde. L'Afrique a souffert de plusieurs flambées de maladie à virus Ebola
\end{abstract}


(MVE); apprendre du passé est un bon moyen de préparer l'avenir. Nous espérons mettre en évidence certaines des leçons tirées de la réponse de l'Afrique aux épidémies précédentes qui peuvent aider à lutter contre la pandémie ravageuse de coronavirus.

Mots clés: Ebola, COVID-19, OMS, transmission, mondial

\section{Applying lessons of Ebola out- break response to the COVID-19 pandemic response}

In the wake of COVID-19 pandemic, Hossain et al., (1) believes that fake news, rumours and doubts have been disseminated from all angles especially the social media, giving rise to mass panic and lack of confidence in the COVID-19 response by many communities. According to the Medicins Sans Frontieres (2), community engagement must form the cornerstone of any response as it was key in ending previous Ebola outbreaks in different parts of Africa. The World Health Organization (WHO) states that community engagement is very necessary in discovering new cases of Ebola virus disease (EVD) and in contact tracing of people sick with Ebola and community members need training in many aspects of the response so that they can contribute in ending the transmission of EVD. This was demonstrated when Ebola outbreak began in Sierra Leone in 2014, the ministry of health began a massive community-based intervention where community and religious leaders, volunteers and activists were trained on Ebola response from public sensitization to contact tracing, which was very helpful as $70.8 \%$ of 72 cases reported in three communities was done by trained local community members (3).

In responding to the 2014-2016 West Africa Ebola outbreak, the International Federation of Red Cross (IFRC) and Red Crescent Societies (RCS) mobilized 600,000 community members as volunteers across 10 countries in Africa. This was counted as a big success in the fight against Ebola epidemic as was corroborated my Mrs Khadidiatou Baro, an Ivorian, who said, "we did not know what quarantine was and why it is important for stopping Ebola. Many people would not allow any of their family members to be quarantined. But the Red Cross community engagement volunteers convinced us about the importance of quarantine and we now accept it in our communities" (4).

To achieve the goal of flattening the global SARS-COV-2 infection curve, community leaders, health workers, volunteers and various social groups within the communities must be made to champion the fight against COVID-19. Various communities especially in low -and - middle - income-countries (LMICs) without access to adequate information must realize the importance of social distancing and hygienic practices in breaking the chain of community transmission; they must learn to report cases immediately and also participate in contact tracing. This training will come by community engagement.

Vaccines have been crucial in the eradication of some deadly diseases such as smallpox and in reducing harms caused by these pathogens (5). The WHO states that 2013-2016 West Africa Ebola outbreak which killed more than 11,300 people has exposed the importance of a vaccine. The necessity of a vaccine warranted the approval of an experimental vaccine for use by the regulatory and ethics review boards in the Democratic Republic of Congo on May 29, 2017 (6). Therefore, following the resurgence of Ebola in DRC in April 2018, the ministry of health sprang into action, and on May 21, 2018 began a radical but important ring vaccination using rVSV-ZEBOV to vaccinate primary and secondary contacts of diagnosed cases. This proved very helpful as 3,796 individuals who were immediately vaccinated were not infected. Lesson learnt is that 'what has worked before can work again' as ring vaccination has been used before in the eradication of smallpox (7). The rVSV-ZEBOV vaccine produced by Merck went through clinical trials during the 2013-2015 West Africa Ebola epidemic and was found to be $100 \%$ efficacious, and was $97.5 \%$ effective in the 2018 Kivu outbreak (8).

According to the Global Alliance for Vaccines and Immunization (GAVI) (9), "developing a vaccine against COVID-19 is the most pressing challenge of our time". COVID19 vaccine could be the game changer in the global struggle against COVID-19 pandemic, a view that was reaffirmed by $\mathrm{Dr}$ Seth Berkley, CEO of GAVI who believes that "COVAX is the only truly global solution to COVID-19 pandemic" (10). Calls have been made by funders, manufacturers and scientists to speed up the vaccine development, so far, 70 vaccines and numerous therapeutics are in clinical trials in different parts of the world (11). To show the importance of effective vaccine, more than 150 countries have agreed to be part of the COVID-19 vaccine global access facility which will ensure the equitable distribution of the vaccines to participating countries through COVAX using the criteria of need, vulnerability and level of threat to determine further distribution of the vaccine when ready (10). Knowledge derived from Ebola and SARS-COV responses has contributed in some measure in designing innovative approaches for COVID-19 vaccine 
development which is expected to be the quickest vaccine development in history (12). Just like in DRC Ebola outbreak of 2018, a COVID-19 vaccine will assist in breaking the chain of transmission in the primary and secondary contacts of infected persons. It is expected that by the end of 2021, COVAX would have delivered more than 2 billion doses of safe and effective vaccines (10).

According to the World Health Organization 2016 [13], "a well-functioning health system working in harmony is built on having trained and motivated health workers, a well maintained infrastructure and a reliable supply of medicines and technologies backed by adequate funding, strong health plans and evidence -based policies." The weak health system in Africa was heavily exposed during the Ebola outbreak that began in Guinea in 2013, and spreading to Liberia and Sierra Leone in $2014(14,15)$. The Republic of Guinea suffers from a critical shortage of healthcare workers with a health workforce density less than 1.5 per 10,000 (14). Apanga and Akparigbo (15) reported that $80 \%$ of Ebola cases in the early days of the outbreak who were diagnosed of Ebola were not admitted by the hospital authorities due to lack of infrastructure (accommodation). Poor infrastructure and weak health systems continue to plague many LMICs in the face of the recent COVID-19. To improve the COVID19 response, national governments must pay more attention to their health systems by increasing funding, quality and quantity of their health workforce (16). This view is reemphasized by Bill Gates (17) who believes that "it's essential to help LMICs strengthen their primary health care systems. When you build a health clinic, you are also creating part of the infrastructure for fighting epidemics."

The 2014-2016 outbreak in West Africa has been described severally as the largest and most complex of all Ebola outbreaks (18), the first case was reported on March 23, 2014 in South Eastern Guinea (19). An important lesson learnt is that outbreak response requires concerted effort and should not be left for any one government or organization (20). The importance of international collaboration was demonstrated when the international community committed USD 100 million to fight the Ebola epidemic of 20142016 which enabled the deployment of more medical personnel to assist in combating Ebola (21). The cross-border collaboration on preparedness and response to Ebola virus and other disease outbreaks which DRC entered in 2019 with 9 neighboring countries is a sign of strong international commitment and willingness to pull resources which will strengthen disease surveillance among the participating countries and improve health security [22].

A joint international collaboration is necessary in the wake of COVID-19 pandemic $(23,24)$. Thanh et al., (25) emphasized the importance of strong international coordination between vaccine developers, regulators and other relevant stakeholders. Momtazmanesh et al., (24) made 2 key observations; first, the quick exchange of genomic sequence of COVID-19 by many researchers globally, and second, the launch of the solidarity trial which has at least 10 countries in participation with the WHO at the helm of the study. Those two observations are marks of international coordination and cooperation. During this COVID-19, we have seen countries help each other; from donating ventilators to taking in very critical patients (26). Furthermore, the United Nations (UN) believes that "the only way to fight COVID-19 is through a global approach" and in demonstration of its commitment to humanitarian response has donated USD 2 billion to assist 51 countries across the globe to cushion the effect of COVID-19 (27). More international collaborations will be needed to facilitate vaccine delivery and break the barriers to vaccine licensing. LMICs will require great help to bounce back from the heavy blow of COVID-19, and this can only come through international solidarity.

\section{Conclusion:}

By joining together and engaging communities, COVID-19 can be contained just like the EVD. It is important to note that the world will only be safe when we are all safe. The COVID-19 pandemic has exploited any and all cracks in humanity. In the war against COVID-19, health system resilience, accountability and integrity are more important than ever. The health systems of some high-income-countries have become overwhelmed by the rising number of infected cases and deaths from the disease. The weaker, corruption-prone and less resilient health systems of many LMICs are even more vulnerable, and some may even collapse.

Research has underscored the vulnerability of Africa's health system. A consistently solid and accountable health system has eluded the continent. The requisite health resources are also in short supply. Also, Ebola and COVID-19 have demonstrated the need for universal health coverage. According to Tedros Adhanom (WHO Director General), "global health is only as strong as its weakest link". Whether it is Ebola, COVID-19, measles, chickenpox or another pathogen, universal health coverage is our best defense. This means investing in surveillance, health workforce and primary health care as key compo- 
nents to ensuring quality health services for all.

\section{References:}

1. Hossain, M. S., Ferdous, S., and Siddiqee, M. H. "Mass panic during COVID-19 outbreak - a perspective from Bangladesh as a High-Risk Country". J Biomed Analy. 2020; 3(2): 1 - 3. doi: $10.30577 /$ jba.V3i2.40.

2. Medecins Sans Frontieres. Six lessons learned as Ebola outbreak in northeastern DRC ends. https://www.msf.org/Six-lessons-learned-drcebola-outbreak-ends. June 26, 2020.

3. Li, Z. J., Tu, W. X., Wang, X. C., et al. A practical community-based response strategy to interrupt Ebola transmission in Sierra Leone, 2014-2015. Infect Dis Poverty. 2016; 5: 74. doi:10. 1186/540249-016-0167-0.

4. International Federation of Red Cross and Red Crescent Societies. Red Cross mobilizes 600,000 Community members in fight against Ebola. http://www.google.com/url?Sa =t\&Source $=$ web\&rct=j\&u $\mathrm{rl}=\mathrm{https}$ ///reliefweb.int/sites/reliefweb.int/files/ resources/IFRC CEA-in-Ebola-prepared- ness, 2017

5. Rey-Jurado, E., Tapia, F., Munoz-Durango, N. et al. Assessing the importance of domestic vaccine manufacturing centres: an overview of immunization programs, vaccine manufacture and distribution. Front Immunol. 2018; 9: 26. doi:10.3389/fimmu.2018.00026.

6. Maxmen, A. Ebola vaccine approved for use in ongoing outbreak.

https://www.nature.com/news/ebola-vaccineapproved-for-use-in-ongoing-outbreak-1.220. May 30, 2017.

7. Wells, C. R., Pandey, A., Parpia, A. S., et al. Ebola vaccination in the Democratic Republic of Congo. Proceedings of the National Academy of the United States of America. 2019; 116: 10178-10183.

https://doi.org/10.1073/pnas.1817329116.

8. Schwartz, D. A. Maternal and Infant Death and the Rvsv-ZEBOV vaccine through three recent Ebola virus epidemics-West Africa, DRC Equateur DRC Kivu: 4 years of Excluding Pregnant and Lactating women and their infants from Immunization. Curr Trop Med Rep. 2019; 6: 213-222. https://doi.org/10.1007/s40475019-00195-w.

9. Global Alliance for Vaccines and Immunization COVAX, the ACT-Accelerator vaccines pillar. https://www.google.com/search?q=COVAX\%2C+the+act-accelerator+vaccines+pillar\&oq= COVAX. April 14, 2020.

10. World Health Organization. More than 150 countries engaged in COVID-19 vaccine global access facility. https://www.who.int/news-room/ detail/15-07-2020-more-than-150-countriesengaged-in-COVID-19-vaccine-global-accessfacility. July 2020

11. World Health Organization. COVID-19: What we know about the future of COVID-19 vaccine. https://www.who.int/China/news/featurestories/COVID-19-what-we-know-about-thefuture-COVID-19-vaccines. Apr 24, 2020
12. UNICEF. Vaccinations and COVID-19: What parents need to know.

https://www.unicef.org/coronavirus/vaccination s-and-COVID-19-what-parents-need-to-know. April 23, 2020.

13. World Health Organization. Health systems: key expected results.

https://www.who.int/healthsystems/about/progr ess-challenges/en/. June 2, 2016

14. Shoman, H., Kara Fillakis, E., and Rawaf, S. The link between the West African Ebola Outbreak and health systems in Guinea, Liberia and Sierra Leone: a systemic review. Glob HIth. 2017; 13: 1. https://doi.org/10.1186/s/2992-016-0224-2.

15. Apanga, P. A., and Akparigbo, R. Ebola: A call to strengthen the health care system and surveillance in West Africa. IJHSR. 2015; 5 (1): 275-273

16. Ezezika, O., and Keita, A. K. Outsmarting Ebola through stronger national health programs. Scientific African 7. 2020.

https://doi.org/10.1016/j.sciaf.2020.e00309.

17. Gates, B. Responding to COVID-19-A-once-in-acentury-pandemic-? New Engl J Med. 2020. doi:10.1056/NEJMp2003762.

18. World Health Organization. Ebola virus disease. https://www. who.int/health-topics/ebolatab=tab 12020.

19. Centre for Disease Control. 2014-2016 Ebola outbreak in West Africa. 2020 www.cdc.gov/vhf/ebola/history/2014-2016outbreak/index.html anchor 1515001446180.

20. World Health Organization Partners in Ebola Response.www.int/csr/disease/ebola/partnerships/en/.

21. Green, A. WHO and partners launch Ebola response plan. Lancet. 2014; 384: 481.

22. World Health Organization. Ten African countries endorse cross-border collaboration framework on Ebola outbreak preparedness and response.www.afro.who.int/news/ten-africancountries-endorse-cross-border-collaboratonframework-ebola-outbreak-preparedness.

October 21, 2019.

23. Spinelli, A., and Pelliono, G. COVID-19 pandemic: perspectives on an unfolding crisis. Br J Surg. 2020. doi:10.1002/bjs.11627.

24. Momtazmanesh, S., Ochs, H. D., Uddin, L. Q., et al. All together to fight COVID-19. Am J Trop Med Hyg. 2020; 102 (6): 1181-1183.

25. Thanh Le, T., Andreadakis, Z., Kumar, A., et al. The COVID-19 vaccine development landscape. Nat Rev Drug Discov. 2020; 19: 305-306

26. European Parliament. Solidarity: How EU countries help each other fight COVID-19. http://www.europarl.europa.eu/news/en/headlin es/society/20200402STO76415/solidarity-howeu-countries-help-each-other-fight-COVID-19. April 8, 2020.

27. UNICEF. COVID-19 Global humanitarian Response plan.

https://www.unicef.org/thailand/pressrelease/COVID-19-global-humanitarianresponse-plan. March 26, 2020. 